\title{
UJI AKTIVITAS ANTIOKSIDAN EKSTRAK METANOL DAUN CIPLUKAN MENGGUNAKAN METODE 2,2-DIPHENYL 1-PICRILHIDRAZYL (DPPH)
}

\author{
Rosa Devitria $^{1 *}$, Harni Sepriyani ${ }^{2}$, Seftika Sari ${ }^{3}$ \\ 1*Universitas Abdurrab, Jalan Riau Ujung No. 73 Pekanbaru \\ ${ }^{2}$ Universitas Abdurrab, Jalan Riau Ujung No. 73 Pekanbaru \\ ${ }^{3}$ Sekolah Tinggi Ilmu Farmasi Riau, \\ e-mail: 1* rosa.devitria@univrab.ac.id, ${ }^{2}$ harni.sepriyani@univrab.ac.id, ${ }^{3}$ seftika1987.apt@gmail.com
}

\begin{abstract}
ABSTRAK
Pemanfaatan obat-obatan yang bersifat alami telah menjadi pilihan bagi masyarakat Indonesia. Berbagai jenis tanaman di Indonesia telah digunakan secara turun menurun di masyarakat, tetapi belum dapat dimanfaatkan secara optimal. Pada pohon ciplukan mengandung senyawa aktif dan dapat mengatasi berbagai penyakit seperti kanker, rematik, jantung koroner dan katarak diperlukan senyawa yang memiliki aktivitas antioksidan. Penelitian ini bertujuan untuk mengetahui aktivitas antioksidan yang terdapat pada ekstrak metanol daun ciplukan. Salah satu metode pengukuran radikal bebas oleh senyawa antioksidan dengan menggunakan metode 2,2-diphenyl-1-picrylhydrazyl(DPPH). Metode 2,2-diphenyl-1picrylhydrazyl(DPPH)merupakan suatu metode pengukuran antioksidan yang sederhana, cepat dan tidak membutuhkan banyak reagen. Tumbuhan yang mempunyai potensi sebagai penghambat radikal bebas ialah ciplukan. Setelah diuji dari hasil penelitian pada ekstrak metanol daun ciplukan didapatkan $\mathrm{IC}_{50}$ sebesar 820,5695 ppmyang artinya sangat lemah namun masih berpotensi sebagai antioksidan.
\end{abstract}

Kata kunci : Antioksidan, Daun Ciplukan, DPPH

\section{PENDAHULUAN}

Indonesia memiliki keanekaragaman tanaman yang melimpah termasuk tanaman yang memiliki khasiat sebagai obat.Pemanfaatan obat-obatan yang bersifat alami telah menjadi pilihan bagi masyarakat Indonesia. Berbagai jenis tanaman di Indonesia telah digunakan secara turun temurun di masyarakat, tetapi belum dapat dimanfaatkan secara optimal untuk mengatasi berbagai penyakit seperti kanker, rematik, jantung koroner dan katarak (Satria, 2013). Tanaman ciplukan merupakan salah satu tanaman herbal yang mampu menginduksi sel kanker pada payudara dengan nilai $\mathrm{IC}_{50}$ sebesar $187 \mathrm{ppm}$, dan merupakan salah satu tanaman yang berpotensi sebagai antioksidan (Luliana dkk, 2018).

Antioksidan merupakan molekul stabil yang dapat menghambat reaksi oksidasi yang akan menyumbangkan elektron ke radikal bebas kemudian menetralkannya dan molekul yang sangat reaktif akibat kerusakan sel, asam lemak tak jenuh, membran dinding sel, pembuluh darah, asam deoksiribonukleat dan jaringan lipid sehingga menimbulkan penyakit di dalam tubuh (Niah dan Helda, 2016). Berdasarkan sumbernya antioksidan dapat berupa antioksidan alami dan antioksidan sintetik. Antioksidan alami mampu melindungi tubuh terhadap kerusakan yang disebabkan senyawa oksigen reaktif, menghambat terjadinya 
penyakit degeneratif. Antioksidan sintetik dapat menimbulkan efek samping yang berbahaya bagi kesehatan pada tubuh manusia karena bersifat karsinogenik. Oleh karena itu, diperlukan senyawa antioksidan yang dapat meredam efek negatif dari radikal bebas(Winarsi, 2007).

Radikal bebas merupakan atom atau molekul yang mengandung satu atau lebih elektron tidak berpasangan dan sangat reaktif sehingga untuk menjadi stabil ia cenderung akan mengambil elektron dari molekul lain yang menimbulkan tidak normalnya molekul lain. Dan dapat merusak jaringan lain. Diperlukan senyawa yang dapat meredam efek negatif dari radikal bebas yaitu antioksidan (Jami'ah dkk, 2018). Salah satu metode pengukuran radikal bebas oleh senyawa antioksidan dengan menggunakan metode 2,2-diphenyl-1-picrylhydrazyl(DPPH). Metode 2,2-diphenyl-1-picrylhydrazyl(DPPH)merupakan suatu metode pengukuran antioksidan yang sederhana, cepat dan tidak membutuhkan banyak reagen. Metode ini didasarkan reduksi 2,2-diphenyl-1picrylhydrazyl(DPPH)terhadap senyawa penghambat radikal bebas yang menyebabkan terjadinya perubahan dari warna ungu menjadi warna kuning.DPPHawaldapat diukur menggunakan spektrofotometer pada panjang gelombang 520 nm(Masrifah dkk., 2017).

Menurut penelitian Permatasari dkk (2018),pemberian ekstrak metanol daun ciplukan dapat menurunkan kadar tulang mandibula pada tikus putih. Terdapat hubungan antara ekstrak metanol daun ciplukan dengan penurunan kadar MDA tulang mandibula tikus. Pemberian ekstrak metanol daun ciplukan dosis $1.500 \mathrm{mg} / \mathrm{kg}$ dapat memperbaiki Minimum Descent Altitude (MDA) tulang mandibula tikus seperti keadaan normal. Dalam daun ciplukan mengandung physalin sebagai alternatif untuk menurunkan jumlah radikal bebas pada tulang manndibula tikus.Hasil penelitian Aldi dkk (2014),didapatkan ekstrak etanol daun ciplukan memiliki aktivitas antioksidan dan kapasitas fagositosis makrofag yang signifikanpada dosis $100 \mathrm{mg} / \mathrm{kg}$ antara kontrol positifnya.pada tikus putih dimana bobot limfa relatif berbeda jika dibandingkan dengan kelompok kontrol.

Tujuan penelitian ini adalah untuk mengetahui kemampuan dari ekstrak metanol daun ciplukan dalam menghambat radikal bebas dengan menggunakan metode DPPH dan menentukan nilai $\mathrm{IC}_{50}$ pada uji aktivitas antioksidan ekstrak metanol daun ciplukan.

Ciplukan dapat dimanfaatkan sebagai anti hiperglikemik, antibakteri, antivirus, imunostimulan dan imunosupresan (imunomodulator), antiinflamasi, antioksidan, analgesik, dan sitotoksik. Buah ciplukan sendiri sering dimakan langsung untuk mengobati epilepsi, sulit buang air kecil dan penyakit kuning. Bagian tanaman ciplukan yang digunakan sebagai obat adalah seluruh bagian tanaman, baik segar maupun telah dikeringkan (Sasmito, 2017). Pada bagian buah kaya akan zat aktif flavonoid dengan presentase ekstrak buah $300 \mu \mathrm{g} / \mathrm{mL}$. Flavonoid merupakan salah satu senyawa antioksidan yang berfungsi mengatasi atau menetralisir radikal bebas sehingga diharapkan dengan pemberian antioksidan tersebut kerusakan sel tubuh dapat dihambat serta dapat mencegah terjadinya kerusakan tubuh dan timbulnya penyakit (Oetari, 2019).

Antioksidan adalah senyawa yang mampu menghilangkan, membersihkan, dan menahan pembentukan oksigen reaktif atau radikal bebas dalam tubuh. Antioksidan merupakan senyawa pemberi elektron (electron donor) atau reduktan. Senyawa ini memiliki berat molekul kecil, tetapi mampu mengaktivasi berkembangnya reaksi oksidasi, dengan mengikat radikal bebas dan molekul yang sangat aktif. Akibatnya kerusakan sel akan dihambat. Fungsi utama antioksidan digunakan untuk memperkecil terjadinya proses oksidasi lemak dan minyak. Memperkecil terjadinya proses kerusakan dalam makanan,perpanjang masa pemakian dalam industri makanan, meningkatkan stabilitas lemak yang terkandung dalam makanan (Winarsi, 2007).

Pengukuran antioksidan dengan menggunakan metode penangkalan radikal bebas DPPH(2,2-diphenyl1-picrylhydrazl). Metode DPPH (2,2-diphenyl-1picrylhydrazl) merupakan metode yang sederhana, cepat dan mudah untuk penapisan aktivitas penangkap radikal bebas, metode ini terbukti akurat dan praktis. Uji DPPH (2,2-diphenyl-1-picrylhydrazl) berperan sebagai radikal bebas yang mengandung senyawa nitrogen yang tidak stabil dan berwarna ungu gelap. Setelah bereaksi dengan senyawa antioksidan,DPPH (2,2-diphenyl-1-picrylhydrazl) tersebut tereduksi dan warna akan berubah menjadi kuning.Perubahan warna tersebut akan diukur dengan spektrofotometer, penurunan intensitas warna yang terjadi disebabkan oleh kekurangan ikatan rangkap terkongjungsi pada DPPH (2,2-diphenyl-1-picrylhydrazl) hal ini terjadi apabila adanya penangkapan satu elekron oleh zat antioksidan, menyebabkan tidak adanya kesempatan elekron tersebut untuk beresonasi(Masrifah dkk., 2017).Metode ini sangat cocok untuk skrining awal berbagai sampel, terutama ekstrak tumbuhan (Octavia, 2010). Interpretasi hasil pengujian antioksidan dengan motode DPPH dilakukan dengan variabel kapasitas antioksidan dan presentase penghambat. Kapasitas penghambat dihitung berdasarkan nilai Inhibitor Consentration $\left(\mathrm{IC}_{50}\right)$, yaitu konsentrasi senyawa antioksidan yang memberi penghambatan sebesar $50 \%$. Nilai $\mathrm{IC}_{50}$ berbanding terbalik dengan kapasitas antioksidan, artinya semakin kecil nilai $\mathrm{IC}_{50}$ maka semakin tinggi kapasitas antioksidan sampel tersebut (Susanto, 2019). 


\section{METODE PENELITIAN}

Alat-alat yang digunakan dalam penelitian adalah neraca analitik, vial, mikropipet reader berthold model LB-941, dan peralatan gelas yang umum digunakan dilaboratorium. Bahan yang digunakan dalam penelitian ini yaitu daun ciplukan, alumunium foil, metanol, aquadest, kertas saring, DPPH (2,2Diphenyil-1-picrylhidrazil).

\subsection{Ekstraksi sampel secara maserasi}

Daun ciplukan dicuci bersih dan diiris, ditimbang sebanyak 100 gram, lalu dikeringkan pada suhu ruangan kemudian ditimbang sampai beratnya konstan. Setelah kering dan didapatkan berat konstannya, sebanyak 10 gram daun ciplukan dimasukan ke dalam botol penampung. Lalu masukan metanol sampai sampel terendam dan kemudian diamkan 3x24 jam. Kemudian hasil maserasi sampel disaring menggunakan kertas saring dimasukan ke dalam botol vial dan diuapkan dengan cara dianginkan pada suhu ruangan hingga kering, kemudian dilakukan uji fitokimia dan uji aktivitas antioksidan.

\subsection{Analisis aktivitas antioksidan}

Uji aktivitas antioksidan dilakukan dengan menggunakan microplatet reader two fold delution dengan menggukan metode 2,2diphenyl-1picrylhydrazyl (DPPH)panjang gelombang $520 \mathrm{~nm}$. Baris A dimasukkan sampel sebanhak $100 \mu \mathrm{L}$. Plate terdiri dari baris A-H (masing-masing berjumlah 12 sumur). Sebanyak $50 \mu \mathrm{L}$ metanol dimasukkan pada masing-masing sumur pada baris B-F. Baris A pipet sebanyak $50 \mu \mathrm{L}$ masukkan kebaris $\mathrm{B}$, baris $\mathrm{B}$ dipipet $50 \mu \mathrm{L}$ dimasukkan kebaris $\mathrm{C}$ dan dilakukan sampai baris $\mathrm{F}$, baris $\mathrm{F}$ dipipet $50 \mu \mathrm{L}$ lalu dibuang, sedangkan baris G-F diisi dengan metanol $50 \mu \mathrm{L}$, khusus pada baris $\mathrm{H}$ diisi hanya sumur 1-6. Baris A-G ditambahkan DPPH sebanyak $80 \mu \mathrm{L}$, dengan konsentrasi $80 \mu \mathrm{g} / \mathrm{mL}$. kemudian diinkubasi selama 30 menit. Aktivitas penangkal radikal diukur sebagai penurunan absorbansi DPPH dengan microplate reader dan oleh data.

Kontrol positif yang digunakan sebagai pembanding adalah larutan asam askorbat dengan konsentrasi 50 ppm. Nilai inhibisi \% dihitung dengan rumus sebagai berikut:

$\%$ Inhibisi $=\frac{(\text { A kontrol }- \text { Asampel })}{\text { Akontrol }} \times 100 \%$

Keterangan : Akontrol = Absorbansi tidak mengandung sampel

$$
\text { : Asampel }=\text { Absorbansi sampel }
$$

Adapun rumus persamaan linier sebagai berikut:

$$
\mathrm{Y}=\mathrm{aX}+\mathrm{b}
$$

Keterangan: $\quad \mathrm{Y}=$ Absorbansi sampel

$\mathrm{X}=$ Konsentrasi sampel

\subsection{Analisis Data}

Analisis data dilakukan dengan pengukuran absorbansi sampel dan menggunakan rumus \% inhibisi. Data dianalisis dengan cara membuat kurva kalibrasi kemudian memasukan kedalam persamaan regresi linier dari konsentrasi larutan dengan \% inhibisi dan selanjutnya dihitung nilai $\mathrm{IC}_{50}$.

\section{HASIL DAN PEMBAHASAN}

Analisis aktivitas antioksidan dilakukan dengan menggunakan microplate reader two fold delution. Metode yang digunakan yaitu metode DPPH pada panjang gelombang $520 \mathrm{~nm}$. Dari hasil penelitian didapatkan nilai $\mathrm{IC}_{50}$ seperti terlihat pada Tabel 1 dan 2 .

Tabel 1. Persen inhibisi terhadap konsentrasi sampel ekstrak daun ciplukan

\begin{tabular}{cccc}
\hline No. & $\begin{array}{c}\text { Konsentrasi } \\
(\mathbf{p p m})\end{array}$ & \% Inhibisi & $\mathbf{I C}_{\mathbf{5 0}}(\mathbf{p p m})$ \\
\hline 1. & 1000 & 55,3359 & \\
2. & 500 & 40,7114 & \\
3. & 250 & 31,3570 & 820,5695 \\
4. & 125 & 20,9486 & \\
5. & 62,5 & 11,4624 & \\
6. & 31,25 & 2,37154 & \\
\hline
\end{tabular}

Berdasarkan tabel 1. diatas diketahui bahwa aktivitas antioksidan daun ciplukan pada konsentrasi tertinggi didapatkan persen inhibisi sebesar 55,3359\%, pada konsentrasi terendah didapatkan persen inhibisi sebesar 2,37153\%. Maka didapatkan hasil uji aktivitas antioksidan ekstrak daun ciplukan yaitu 820,5695 ppm.

Tabel 2. Persen inhibisi terhadap konsentrasi sampel asam askorbat

\begin{tabular}{cccc}
\hline No. & Konsntrasi (ppm) & \% Inhibisi & $\begin{array}{c}\text { IC50 } \\
(\mathbf{p p m})\end{array}$ \\
\hline 1. & 100 & 98,809 & \\
2. & 50 & 84,126 & \\
3. & 25 & 72,222 & 7,328 \\
4. & 125 & 60,317 & \\
5. & 6,25 & 48,412 & \\
6. & 3,125 & 33,333 & \\
\hline
\end{tabular}

Berdasarkan tabel 2. diatas diketahui aktivitas antioksidan asam askorbat pada konsetrasi tertinggi didapatkan \% inhibisi sebesar 98, $809 \%$, pada konsetrasi terendah didapatkan \% inhibisi sebesar 33,333 \%. Maka didapatkan hasil uji aktivitas antioksidan asam askorbat yaitu 7,328 ppm. 
Penelitian ini bertujuan untuk mengetahui aktivitas antioksidan dengan menggunakan pelarut metanol pada estrak daun ciplukan dan menggunakan metode 2,2-diphenyl-1-picrylhidrazyl (DPPH). Pada perlakuan pertama aktivitas antioksidan menggunakan sampel daun ciplukan yang diiris tipis, sampel yang telah diiris tipit memiliki ukuran yang kecil sehingga memudahkan metabolit sekunder pada sampel tersebut tertarik dan memudahkan pada saat proses maserasi. Pembuatan ekstrak diawali dengan menimbang ekstrak sebanyak 10 gram lalu dilakukan perendaman dengan pelarut metanol. Hasil maserasi sampel daun ciplukan berupa padatan. Pelarut yang digunakan untuk melakukan maserasi adalah metanol karena memiliki sifat yang lebih polar dibandingkan dengan pelarut organik lainnya dan memiliki jumlah atom $\mathrm{C}$ yang lebih sedikit, sehingga memudahkan senyawa organik yang bersifat polar lebih cepat terikat(Satria dkk, 2013).

Metode yang digunakan dalam pengujian aktivitas antioksidan adalah metode serapan radikal DPPH karena merupakan metode yang sederhana, cepat dan mudah untuk penapisan aktivitas penangkap radikal bebas, metode ini terbukti akurat dan praktis. Pengukuran aktivitas antioksidan metode DDPH menggunakan spektrofotometer pada panjang gelombang $520 \mathrm{~nm}$. Konsentrasi sampel yang digunakan dilihat dalam beberapa konsentrasi yaitu 1000 ppm, 500 ppm, 250 ppm, 125 ppm, 62,5 ppm dan $31,25 \mathrm{ppm}$. Aktivitas antioksidan sampel ditentukan oleh besarnya daya hambat radikal DPPH hingga didapatkannya nilai $\mathrm{IC}_{50}$ (Masrifah, 2017).

Nilai $\mathrm{IC}_{50}$ merupakan senyawa antioksidan yang memberikan inhibisi sebesar 50\% yang artinya pada konsentrasi tersebut antioksidan dapat menghambat radikal bebas sebesar $50 \%$. Nilai $\mathrm{IC}_{50}$ pada Asam askorbat sebagai kontrol psitif adalah sebesar 7,328 ppm (Tabel 2.), aktivitas antioksidannya merupakan golongan sangat kuat karena Asam Askorbat merupakan senyawa yang sudah murni. Sedangkan pada sampel ekstrak daun ciplukan didapatkan nilai $\mathrm{IC}_{50}$ sebesar 820,5695 ppm (Tabel 1). Suatu zat mempunyai sifat antioksidan bila nilai $\mathrm{IC}_{50}$ kurang dari 50 ppm, antioksidan dikategorikan kuat jika $\mathrm{IC}_{50}$ bernilai 50-100 ppm, antioksidan dikategorikan sedang jika IC50 bernilai 100-150 ppm, dan antioksidan dikategorikan lemah jika $\mathrm{IC}_{50}$ bernilai lebih dari $150 \mathrm{ppm}$. Semakin besar nilai $\mathrm{IC}_{50}$ maka dapat dikatakan zat tersebut aktivitas antioksidannya sangat lemah(Sarfina, 2017).

Suatu zat mempunyai sifat antioksidan yang sangat baik bila nilai $\mathrm{IC}_{50}$ kurang dari 200 ppm. Bila nilai IC $_{50}$ antara 200-1000 ppm zat tersebut kurang aktif namun masih berpotensi sebagai antioksidan(Satria., dkk (2013).Penelitian yang dilakukan oleh Amanda dkk., (2019) menyatakan bahwa rendahnya aktivitas antioksidan ini kemungkinan disebabkan oleh berbagai faktor, diantaranya karena metode ekstraksi yang digunakan kemungkinan tidak cukup menarik komponen kimia yang bersifat antioksidan. Selain itu karena asam aksorbat merupakan senyawa murni sedangkan ekstrak metanol daun ciplukan masih senyawa campuran dan belum diketahui kandungan senyawanya yang bersifat antioksidan, dimana senyawanya kemungkinan bisa mempengaruhi aktivitas antioksidan ekstrak metanol daun ciplukan.

\section{SIMPULAN}

Ekstrak metanol daun ciplukan memiliki aktivitas antioksidan tetapi sangat lemah dikarenakan nilai $\mathrm{IC}_{50}$ didapatkan hasil sebesar 820,5695 ppm. Pada konsentrasi tertentu ekstrak metanol daun ciplukan tidak mempunyai aktivitas antioksidan yang sebanding dengan asam askorbat bila dilihat dari nilai $\mathrm{IC}_{50}$.

\section{UCAPAN TERIMA KASIH}

Penulis mengucapkan terima kasih kepada seluruh pihak yang telah memberi dukungan terhadap penelitian ini.

\section{DAFTAR PUSTAKA}

Satria, M. D., Sari, R., dan Wahdaningsih, S. 2013. Uji Aktivitas Antioksidan Ekstrak n-Heksan Buah Lakum (Cayratia trofolia) dengan Metode DPPH. Jurnal ilmiah, Volume 5(3): Halaman 7.

Luliana, S., Riza, H., dan Iswahyudi, I. (2018). Pengaruh Metode Pengerimgan Terhadap Aktivitas Antioksidan Ekstrak Etanol Daun Physalis angulata L. Jurnal Farmasains. Volume 5(1): Halaman 15-19

Niah, Rdan Helda. 2016. Aktivitas Antioksidan Ekstrak Etanol Kulit Buah Naga Merah Daerah Pelaihari Kalimantan Selatan dengan Metode DPPH (2,2-difenil-1-pikrilhidrazil). Jurnal Pharmascience. Volume 03: Halaman 36-42.

Winarsi, H. 2007. Antioksidan Alami dan Radikal Bebas Potensi dan Aplikasinya dalam Kesehatan.Kanisius.Yogyakarta.

Jami'ah, S. R., Ifaya, M., Pusmarani, J., \& Nurhikma, E. (2018). Uji Aktivitas Antioksidan Ekstrak Metanol Kulit Pisang Raja (Musa Paradisiaca sapientum) Dengan Metode DPPH $(2,2-$ Difenil-1-Pikrilhidrazil). Jurnal Mandala Pharmacon Indonesia, 4(1), 33-38

Masrifah.Rahma, N. dan Abram, H, P. 2017.Uji Aktivitas Ekstrak Daun dan Kulit Labu Air (Lagennaria siceruruai (Molina) Standl).Jurnal Akad.Kim. Volume 6 (2) : Halaman 96-106.

Permatasari, N., Kumala, Y. R., dan Tito, S. (2018). Efek Ekstrak Daun Ciplukan (Physalis minima L.) Terhadap Kadar Malondialdehid Tulang Mandibula Tikus Wistar. Abstrak. 2(1)

Aldi, Y., Aria, M., dan Erman, L. (2014). Uji Efek Stimulasi Ekstrak Etanol Herba Ciplukan (Physalis angulata L.) Terhadap Aktivitas dan Kapasitas Fagositosis Sel Magrofag Pada Mencit Putih Betina. Scintia. Volume 4(8): Halaman 38-41.

Sasmito, E. 2017. Imunomodulator Bahan Alami. (T. A. Prabawati, 
Jurnal Penelitian Farmasi Indonesia 9(1), Juni 2020

ISSN : 2302-187X

$e$-ISSN 2656-3614

Ed.). Yogyakarta: Rapha Publishing.

Oetari, S. U. 2019. Khasiat Obat Tradisional sebagai Antiksidan Diabetes. Yogyakarta:Rapha Publishing.

Octavia, D. R. 2009. Uji Aktivitas Penangkapan Ekstrak Petroleum Eter, Etil Asetal Dan Etanol Daun Binahong (Anreder Acordifolia (Tenote) Steen) Dengan Metode DPPH (2,2 Dipenil - 1 - Pikrilhidrazil). Skripsi. Universitas muhammadiyah Surakarta.

Susanto, E. 2019. Peptida Boiaktif Sebagai Antioksidan Eksplorasi Pada Ceker Ayam. Deepublish. Yogyakarta.

Satria, M. D., Sari, R., dan Wahdaningsih, S. 2013. Uji Aktivitas Antioksidan Ekstrak n-Heksan Buah Lakum (Cayratia trofolia) dengan Metode DPPH. Jurnal ilmiah, Volume 5(3): Halaman 7.

Sarfina, J., Nurhamidah., dan Handayani, D. 2017. Uji Aktivitas Antioksidan dan Antibakteri Ekstrak Daun Ricinus commnis L (Jarak Kepyar). Jurnal Pendidikan dan Ilmu Kimia. 1(1): 66-71.

Amanda, T. T. M., Wewenkang, D. S., dan Yudistira, A. (2019). Uji Aktivitas Antioksidan Ekstrak Etanol Kulit Batang Mahoni Menggunakan metode DPPH. Jurnal Ilmiah Farmasi.Volume 8(3): Halaman 132-139. 
Jurnal Penelitian Farmasi Indonesia 9(1), Juni 2020

ISSN : 2302-187X

$e$-ISSN 2656-3614 